\title{
Modulatory properties of Telfairia occidentalis leaf extract on pancytopenia, electrolyte imbalance and renal oxidative damage in rats
}

\author{
Johnson Olaleye OLADELE ${ }^{1}$, Olu Israel OYEWOLE ${ }^{1 *}$, Olamilekan Kabir BELLO² and \\ Oluwaseun Titilope OLADELE ${ }^{1}$
}

\author{
${ }^{1}$ Phytomedicine and Toxicology Laboratories, Department of Biochemistry, Faculty of Basic and Applied Sciences, Osun \\ State University, Osogbo, Nigeria. \\ ${ }^{2}$ Department of Biochemistry, Faculty of Life Sciences, University of Ilorin, Nigeria. \\ ${ }^{*}$ Corresponding author. Email: ioluoye@yahoo.com
}

Copyright () 2017 Oladele et al. This article remains permanently open access under the terms of the Creative Commons Attribution License 4.0, which permits unrestricted use, distribution, and reproduction in any medium, provided the original work is properly cited.

Received 30th April, 2017; Accepted 25th May, 2017

\begin{abstract}
Telfairia occidentalis is a medicinal plant acclaimed to possess many therapeutic potential. The study was carried out to investigate the possible modulatory effects of aqueous leaf extract of $T$. occidentalis on chemical-induced oxidative stress, renal dysfunction and pancytopenia in rats. Twenty-four (24) adult male rats were divided into 4 groups of 6 rats each. Group I received distilled water, group II, III and IV were administered $5 \mathrm{mg} / \mathrm{kg}$ body weight of cadmium chloride to induce oxidative stress. Group III and IV were treated with 200 and $400 \mathrm{mg} / \mathrm{kg}$ body weight respectively of aqueous leaf extract of $T$. occidentalis for 14 days while rats in group II were left untreated. Results obtained showed that administration of cadmium caused significant suppression of haematopoiesis, depleted endogenous antioxidants and increased lipid peroxidation in the kidney as well as alteration of serum electrolytes. Treatment with graded doses of $T$. occidentalis leaf extract significantly reversed the cadmium induced-biochemical insults as the extract restored the normal renal integrity and boosted renal antioxidant status in rats. The leaf extract also caused significant boost in haematopoiesis in the rats. This result confirmed that aqueous extract of $T$. occidentalis effectively maintain electrolyte balance, modulates pancytopenia and oxidative renal damage in rats suggesting its protective potentials on anaemia and renal disorders.
\end{abstract}

Keywords: Electrolyte imbalance, oxidative stress, renal damage, pancytopenia, Telfairia occidentalis, Cadmium chloride.

\section{INTRODUCTION}

Medicinal plants possessing natural antioxidants polyphenolic compounds have been shown to have reactive oxygen species (ROS) scavenging and lipid peroxidation prevention effects. Telfairia occidentalis (fluted pumpkin-common name, ugu-lgbo language), is a tropical vine grown in West and Central Africa as leaf vegetable and for its edible seeds. The leaf is used locally as blood booster due to the abundance of blood enriching minerals such as iron, potassium, sodium, phosphorus, vitamins (thiamine, riboflavin, nicotinamide, ascorbic acid) and phytochemicals in the plant (Kayode and Kayode, 2011). T. occidentalis leaf is also used in the treatment of infertility (Nwangwa et al., 2007), liver problem and diabetes (Eseyin et al., 2005; Adaramoye et al., 2007). Experimental evidence has claimed that the plant has positive effect on haematopoiesis (Alada, 2000). The hypolipidemic effect and the therapeutic usefulness of the leaf extract in hypercholestolemia has also been documented (Oboh et al., 2006).

Many heavy metals such as cadmium have been considered to have deleterious effects on human health (Chounwou et al., 2012). Human exposure to cadmium 
may be via medications, cigarette, diets, water, occupation and environmental pollution (Chater et al., 2008). A number of disorders including Parkinson syndrome, hepatorenal degeneration, neuropathies, pneumoconiosis and cancer have been associated with chronic exposure to cadmium (Oyewole et al., 2016).

Upon exposure, cadmium can accumulate in various organs of the body including liver, kidney, pancreas and testis eliciting adverse effects on these organs and altering their physiological and biochemical functions. The kidney is a major target of cadmium-induced toxicity due to the presence of metallothionein, a sulfhydryl group containing protein (Van Kerkhove et al., 2010). Cadmium induced anaemia has been associated with haemolysis and iron-deficient indices (Wang et al., 2012). The present study investigated the ameliorating effects of aqueous leaf extract of $T$. occidentalis on cadmium chloride-induced oxidative stress, renal dysfunction and pancytopenia in rats.

\section{MATERIALS AND METHODS}

\section{Chemicals and reagents}

Urea, creatinine and electrolytes $\left(\mathrm{K}^{+}, \mathrm{Na}^{+}\right.$and $\left.\mathrm{HCO}_{3}{ }^{-}\right)$kits are products of Randox Chemical Limited, England. Antioxidant (CAT, SOD, GST), GSH, ascorbic acid and MDA kits were obtained from Cayman Chemical Michigan, USA. Cadmium chloride is a product of British Drug House Poole, England.

\section{Collection of plant material and aqueous extraction}

Fresh leaves of $T$. occidentalis was purchased from vegetable section of Igbona Market in Osogbo, Osun State, Nigeria. The leaves were thoroughly washed and blended in water. The paste was filtered to obtain a clear aqueous extract of the leaves. The filtrate was air dried to obtain a powdery form which was used to prepare the $200 \mathrm{mg} / \mathrm{kg}$ and $400 \mathrm{mg} / \mathrm{kg}$ body weight of extract used in this experiment.

\section{Experimental animals}

Twenty-four male Wistar albino rats weighing between 130 to140 $\mathrm{g}$ were used for this experiment. The rats were obtained from the Central Animal House, Osun State University Osogbo, Nigeria. The rats were kept in ventilated cage at optimum temperature and $12 \mathrm{hrs}$ light/dark cycle and fed with commercial growers smash and water ad libitum. The experiment was carried out in accordance with current rules and guidelines established for the care of laboratory animals (NRC, 2011). The rats were acclimatized for two weeks before treatment commenced.

\section{Experimental design and dose regimen}

The 24 Wistar albino rats were sorted into four (4) different groups containing six (6) rats each. Average body weight of each animal group were taken and recorded daily. Administration of extract and cadmium chloride was done using the gavage method with the aid of oral canula. The animals were treated daily for 14 consecutive days.

Group I: received distilled water and serve as the control. Group II: received $5 \mathrm{mg} / \mathrm{kg}$ body weight of $\mathrm{CdCl}_{2}$.

Group III: received $5 \mathrm{mg} / \mathrm{kg}$ body weight of $\mathrm{CdCl}_{2}$ and $200 \mathrm{mg} / \mathrm{kg}$ body weight of $T$. occidentalis.

Group IV: received $5 \mathrm{mg} / \mathrm{kg}$ body weight of $\mathrm{CdCl}_{2}$ and $400 \mathrm{mg} / \mathrm{kg}$ body weight of $T$. occidentalis.

\section{Collection of blood samples}

The rats were weighed and sacrificed after $24 \mathrm{hrs}$ of last dose treatment under the influence of chloroform anesthesia. The jugular vein was cut and whole blood for haematological analysis collected into labeled EDTA bottles to prevent clotting. Serum for biochemical analysis were obtained by collecting blood from the jugular vein into separate plain bottles, allowed to clot and centrifuged at $4000 \mathrm{rpm}$ for 30 mins. The serum obtained was stored in a refrigerator at $-4 \stackrel{\circ}{\circ}$ until it was used for biochemical analysis.

\section{Preparation of kidney homogenates}

The rats were quickly dissected and the kidneys harvested. The kidneys were rinsed with $\mathrm{KCl}$ and blotted with filter paper and weighed. They were then chopped into bits and homogenized in 4 volumes of the homogenizing buffer $(0.1 \mathrm{M}$ Tris $-\mathrm{KCl}, \mathrm{pH} 7.4)$ using a Teflon homogenizer. The resulting homogenate was centrifuged at $12,500 \mathrm{~g}$ for 15 mins in a cold centrifuge $\left(4^{\circ} \mathrm{C}\right)$, to obtain the post mitochondrial fraction. The supernatant was collected and used for biochemical analyses.

\section{Measurement of haematological parameters}

Haematological parameters including packed cell volume (PCV), haemoglogbin concentration ( $\mathrm{Hb})$, red blood cell count (RBC), white blood cell count (WBC), lymphocyte, reticulocyte and WBC differential counts were measured using the automated multiparameter blood analyzer SYSMEX KX21 as earlier described by Dacie and Lewis (1991).

\section{Biochemical assays}

Catalase activity in the kidney homogenate was determined according to the method of Sinha (1972). 
Table 1. Haematological parameters in rats administered cadmium chloride and aqueous leaf extract of $T$. occidentalis.

\begin{tabular}{lcccc}
\hline Parameters & Group I & Group II & Group III & Group IV \\
\hline PCV $(\%)$ & $31.87 \pm 2.96$ & $17.20 \pm 2.53^{*}$ & $26.12 \pm 3.08$ & $32.48 \pm 3.42$ \\
Hb Conc. $(\mathrm{g} / \mathrm{dl})$ & $19.75 \pm 1.54$ & $11.87 \pm 1.07^{*}$ & $16.38 \pm 1.40$ & $17.09 \pm 2.02$ \\
RBC $\left(\mathrm{X} 10^{6} \mu \mathrm{l}\right)$ & $8.91 \pm 0.64$ & $3.85 \pm 0.32^{*}$ & $6.68 \pm 0.47$ & $7.44 \pm 0.90$ \\
WBC $\left(\mathrm{X} 10^{3} \mu \mathrm{l}\right)$ & $16.52 \pm 1.92$ & $10.27 \pm 1.55^{*}$ & $14.99 \pm 1.32$ & $15.01 \pm 2.06$ \\
Lymphocyte $(\%)$ & $18.13 \pm 3.01$ & $10.07 \pm 2.58^{*}$ & $15.47 \pm 2.93$ & $16.11 \pm 2.24$ \\
Reticulocytes $(\%)$ & $12.82 \pm 1.86$ & $8.80 \pm 1.21^{*}$ & $11.38 \pm 1.31$ & $12.43 \pm 2.12$ \\
Monocyte (\%) & $50.70 \pm 5.85$ & $38.88 \pm 4.92^{*}$ & $46.47 \pm 5.20$ & $48.66 \pm 5.26$ \\
Eosinophil $(\%)$ & $11.43 \pm 1.74$ & $7.21 \pm 1.09^{*}$ & $9.96 \pm 0.79$ & $10.21 \pm 1.25$ \\
Neutrophil $(\%)$ & $34.34 \pm 3.94$ & $22.82 \pm 4.52^{*}$ & $29.51 \pm 3.88$ & $31.32 \pm 3.17$ \\
Basophil $(\%)$ & $7.18 \pm 0.84$ & $3.22 \pm 0.36^{*}$ & $6.33 \pm 0.64$ & $6.97 \pm 0.51$ \\
\hline
\end{tabular}

Data presented as Mean \pm SD of 6 animals. *Significantly different from normal control group at $P<0.05$.

Table 2. Serum urea, creatinine and electrolytes concentrations in rats administered cadmium chloride and aqueous leaf extract of $T$. occidentalis.

\begin{tabular}{lcccc}
\hline Parameters & Group I & Group II & Group III & Group IV \\
\hline Urea $(\mathrm{mmol} / \mathrm{L})$ & $49.68 \pm 4.66$ & $76.43 \pm 5.71^{*}$ & $50.88 \pm 4.53$ & $51.35 \pm 5.21$ \\
Creatinine $(\mathrm{mmol} / \mathrm{L})$ & $58.61 \pm 5.23$ & $88.53 \pm 8.11^{*}$ & $62.59 \pm 4.10$ & $60.44 \pm 5.21$ \\
$\mathrm{Na}^{+}(\mathrm{mmol} / \mathrm{L})$ & $82.44 \pm 6.21$ & $62.39 \pm 5.43^{*}$ & $75.68 \pm 6.46$ & $78.30 \pm 5.49$ \\
$\mathrm{~K}^{+}(\mathrm{mmol} / \mathrm{L})$ & $68.77 \pm 5.10$ & $89.24 \pm 7.12^{*}$ & $74.33 \pm 6.55$ & $73.90 \pm 4.71$ \\
$\mathrm{HCO}_{3}(\mathrm{mmol} / \mathrm{L})$ & $48.22 \pm 3.78$ & $31.55 \pm 2.66^{*}$ & $34.69 \pm 3.00$ & $38.41 \pm 2.39$ \\
\hline
\end{tabular}

Data presented as Mean \pm SD of 6 animals. ${ }^{*}$ Significantly different from normal control group at $\mathrm{P}<0.05$.

Superoxide dismutase (SOD) was assayed by the method of Misra and Fridovich (1972). The method of Habig et al. (1974) was used in the determination of glutathione S-transferase (GST) activity. The level of reduced glutathione (GSH) in the samples was determined by the method described by Jollow et al. (1974). Lipid peroxidation (malondialdehyde) was assessed by using the procedure of Varshney and Kale (1990). The ascorbic acid concentration was determined according to the method of Jagota and Dani (1982). Serum electrolytes $\left(\mathrm{Na}^{+}, \mathrm{K}^{+}, \mathrm{HCO}_{3}{ }^{-}\right)$, urea and creatinine were measured using the appropriate kits and method described by the manufacturer (Randox).

\section{Statistical analysis}

Data were expressed as mean \pm standard deviation (mean $\pm S D$ ) and analyzed using one-way analysis of variance (ANOVA) with the aid of SPSS 12.0 computer software package (SPSS Inc; Chicago, U.S.A). Student's t-test was employed for comparison between two sets of data and differences at $\mathrm{P}<0.05$ were considered significant.

\section{RESULTS}

Table 1 show the haematological parameters in rats administered cadmium chloride and aqueous leaf extract of $T$. occidentalis. Rats administered cadmium alone (group II) recorded significant reduction in haematological indices (PCV, RBC, WBC, Hb, lymphocytes reticulocytes, monocyte, eosinophil, neutrophil and basophil). This reduction was significantly $(P<0.05)$ reversed following treatment with aqueous leaf extract of $T$. occidentalis (group III and IV).

The results of serum concentrations of urea, creatinine and electrolytes in control and experimental animals are shown in Table 2. Rats exposed to cadmium chloride (group II) showed a significant increase $(P<0.05)$ in serum concentrations of urea and creatinine as compared to the control (group I). Cadmium also caused significant increase $(\mathrm{P}<0.05)$ in $\mathrm{K}^{+}$while it reduced $\mathrm{Na}^{+}$ and $\mathrm{HCO}_{3}{ }^{-}$as compared to the control. The altered values of kidney function indicators were reverted significantly $(P<0.05)$ toward normal in rats treated with 200 and $400 \mathrm{mg} / \mathrm{kg}$ body weight of leaf extract of $T$. occidentalis (group III and IV).

Table 3 shows the effect of cadmium chloride and aqueous leaf extract of $T$. occidentalis on enzymatic and non-enzymatic antioxidants as well as lipid peroxidation in the rat's kidney. Renal SOD, GST, CAT, GSH and ascorbic acid were significantly reduced while lipid peroxidation (MDA concentration) was increased in rats treated with cadmium chloride alone (group II). Adminis- 
Table 3. Some oxidative stress indicators in the kidney of rats administered cadmium chloride and aqueous leaf extract of $T$. occidentalis.

\begin{tabular}{lllll}
\hline Parameters & Group I & Group II & Group III & Group IV \\
\hline SOD $(\mathrm{U} / \mathrm{mg}$ protein) & $41.31 \pm 3.55$ & $25.65 \pm 2.68$ & $35.29 \pm 3.24$ & $38.52 \pm 2.98$ \\
CAT $(\mathrm{U} / \mathrm{mg}$ protein) & $28.16 \pm 2.22$ & $18.47 \pm 3.11$ & $22.82 \pm 2.36$ & $24.43 \pm 2.54$ \\
GST $(\mathrm{U} / \mathrm{mg}$ protein) & $37.89 \pm 3.43$ & $27.56 \pm 2.99$ & $32.10 \pm 2.89$ & $32.78 \pm 3.00$ \\
GSH $(\mu \mathrm{g} / \mathrm{ml})$ & $8.77 \pm 0.88$ & $4.96 \pm 0.42$ & $7.35 \pm 0.54$ & $7.48 \pm 0.47$ \\
Ascorbic acid $(\mu \mathrm{g} / \mathrm{ml})$ & $5.63 \pm 0.57$ & $2.89 \pm 0.41$ & $5.10 \pm 0.32$ & $5.24 \pm 0.51$ \\
MDA (units/mg protein) & $5.49 \pm 0.34$ & $10.21 \pm 0.89$ & $6.96 \pm 0.63$ & $6.87 \pm 0.58$ \\
\hline
\end{tabular}

Data presented as Mean \pm SD of 6 animals. ${ }^{*}$ Significantly different from normal control group at $\mathrm{P}<0.05$.

tration of graded doses of $T$. occidentalis leaf significantly attenuates these antioxidants anomalies in the kidney of experimental rats.

\section{DISCUSSION}

Results in Table 1 indicated a marked general decrease in blood cellular elements in the animals (pancytopenia) following administration of cadmium chloride. Exposure of rats to the metal also resulted in anaemia characterized by significant reduction in PCV and $\mathrm{Hb}$ concentration. However, treatment with aqueous leaf extract of $T$. occidentalis significantly increased $(\mathrm{P}<0.05)$ all the heamatological parameters. The haematinic effect of this extract may be due to the phytochemical constituents of the leaves which consist of blood enriching minerals such as iron, potassium, sodium, phosphorus, vitamins (thiamine, riboflavin, nicotinamide, ascorbic acid) and phytochemicals (Kayode and Kayode, 2011).

The observed increased serum $\mathrm{K}+$ level and decreased serum $\mathrm{Na}^{+}$and $\mathrm{HCO}_{3}{ }^{-}$in rats administered cadmium alone indicates electrolyte imbalance. This result agrees with the previous reports that cadmium intoxication induced abnormal serum electrolytes and hyperkalemia (Tabassum and Bajaj, 2013). This electrolyte imbalance might have resulted due to peroxidation of the polyunsaturated fatty acids in the membrane by cadmium which delocalized $\mathrm{Na}^{+-} \mathrm{K}^{+}-$ATPase from basolateral to apical membrane. The mechanism of cadmium-induced organ damage has been elucidated to be through alteration of transport pathways (Patra et al., 2012), epigenetic aberrations in DNA expression, the disruption of the redox balance resulting in oxidative stress and impairment of mitochondrial functions to induce apoptosis (Matovic et al., 2012). Treatment with aqueous leaf extract of $T$. occidentalis significantly reversed the observed alterations in serum electrolytes suggesting its positive effects on homeostasis.

The observed significant increase in the level of urea and creatinine in the serum of cadmium treated rats (group II) as compared to the normal control (group I) is an indication of renal dysfunction. Urea and creatinine are chiefly excreted from the blood via glomerular filtrations and are routinely measured to assess the kidney health status (Dioka et al., 2004). Increased serum levels of these metabolites are synonymous with decreased in the rate of their excretion which is a pointer to impairment of kidney function (Patil et al., 2007). Aqueous leaf extract of $T$. occidentalis administration significantly normalized the serum levels of urea and creatinine.

The increased lipid peroxidation and depletion of antioxidants levels in the kidney of rats intoxicated with cadmium is synonymous with oxidative stress. This observation might be a consequence of increased free radical formation as well as the disruption of antioxidant status. However, treatment with aqueous extract of $T$. occidentalis significantly reversed these alterations confirming the antioxidant properties of the extract. The polyphenolic content of the leaf extract might have contributed directly to the antioxidant action. It is suggested that polyphenols have inhibitory effects on mutagenesis and carcinogenesis in human (Tsao and Akhtar, 2005). Flavonoids in plants are regarded as antioxidant molecules and could therefore reduce cellular oxidative stress (Oboh et al., 2007).

Lipid peroxidation is known to be one of the principal mechanisms of cell injury in aerobic organisms subjected to oxidative stress (Oboh and Rocha, 2007). Neurodegenerative diseases and aging processes resulting from accumulation of free radicals could be inhibited by antioxidant activities of medicinal plants such as $T$. occidentalis.

\section{Conclusion}

This study demonstrated that aqueous extract of $T$. occidentalis effectively boosted haematopoiesis, corrected electrolyte imbalance, reduced oxidative stress and attenuates renal dysfunction induced by cadmium chloride exposure in rats. This study suggests that the extract has protective potential on chemical-induced pancytopenia and renal oxidative dysfunction. Regular consumption of $T$. occidentalis leaf might therefore be a good remedy for management of anaemia while it also maintains kidney integrity. 


\section{CONFLICT OF INTEREST}

The authors declare that they have no conflict of interest.

\section{REFERENCES}

Adaramoye, O. A., Achem, J., Akintayo, O. O., \& Fafunso, M. A. (2007). Hypolipidemic effect of Telfairia occidentalis (fluted pumpkin) in rats fed a cholesterol-rich diet. Journal of Medicinal Food. 10(2), 330-336.

Alada, A. R. A. (2000). The haematological effects of Telfairia occidentalis diet preparation. Afr. J. Biomed. Res., 3, 85-86.

Chater, S., Douki, T., Garrel, C., Favier, A., Sakly, M., \& Abdelmelek, H. (2008). Cadmium-induced oxidative stress and DNA damage in kidney of pregnant female rats. Comptes rendus biologies, 331(6), 426-432.

Chounwou, P. B., Yedjou, C. G., Patiolla, K., \& Sutton, D. J. (2012). Heavy metal toxicity and the environment. In Molecular, clinical and environmental toxicology, Pp. 133164.

Dacie, J. V., \& Lewis, S. M. (1991). Practical Haematology (7th edn). Churchill Livingstone: Edinburgh. Pp. 1228-1234.

Dioka, C. E., Orisakwe, O. E., Adeniyi, F. A. A., \& Meludu, S. C. (2004). Liver and renal function tests in artisans occupationally exposed to lead in mechanic village in Nigeria. Int. J. Environ. Res. Public Health, 1, 21-25.

Eseyin, O. A., Igboasoiyi, A. C., Oforah, E., Nkop, N., \& Agboke, A. (2005). Hypoglycaemic activity of Telfairia occidentalis in rats. J. Pharmacol. Bioresources, 2, 36-42.

Habig, W. A., Pabst, M. J., \& Jacoby, W. B. (1974). Glutathione transferases: The first enzymatic step in mercapturic acid formation. J. Biol. Chem., 249, 7130-7139.

Jagota, S. K., \& Dani, H. M. (1982). A New colorimetric technique for the estimation of vitamin $\mathrm{C}$ using Folin phenol reagent. Analytical Biochem., 127, 178-182.

Jollow, D. J., Michel, J. R., Zam, N., \& Gillette, J. R. (1974). Necrosis protective role of gluthatthione and evidence for 3,4 bromobenzene oxide as a hepatotoxic metabolite. Pharmacol., 11, 151-169.

Kayode, A. A., \& Kayode O. T. (2011). Some medicinal values of Telfairia occidentalis: A review. Am. J. Biochem. Mol. Biol., 1, 30-38.

Matovic, V., Buha, A., Bulat, Z., \& Dukic-Cosic, D. (2011). Cadmium toxicity revisited: Focus on oxidative stress induction and interactions with zinc and magnesium. Arhiv za higijenu rada i toksikologiju, 62(1), 65-75.

Misra, H. P., \& Fridovich, I. (1972). The role of superoxide anion in the auto-oxidation of epinephrine and a simple assay for superoxide dismutase. J. Biol. Chem., 247, 3170-3175.
National Research Council-NRC (2011). Guide for the care and use of laboratory animals 8th Edition. The National Academies Press.

Nwangwa, E. K., Mordi, J., Ebeye, O. A., \& Ojieh, A. E. (2007). Testicular regenerative effects induced by the extracts of Telfairia occidentalis in rats. Caderno de Pesquisa, Série Biologia, 19, 27-35.

Oboh, G., \& Rocha, J. B. T. (2007). Antioxidant in foods: A new challenge for food processors. Leading Edge Antioxidants Research, Nova Science Publishers Inc., New York, US. Pp. 35-64.

Oboh, G., Nwanna, E. E., \& Elusiyan, C. A. (2006). Antioxidant and antimicrobial properties of Telfairia occidentalis (fluted pumpkin) leaf extracts. J. Pharmacol. Toxicol., 1, 167-175.

Oboh, G., Puntel, R. L., \& Rocha, J. B. T. (2007). Hot pepper (Capsicum annuum, Tepin and Capsicum chinese, Habanero) prevents $\mathrm{Fe}^{2+}$-induced lipid peroxidation in Brainin vitro. Food Chem., 102, 178-185.

Oyewole, O. I., Shoremi, M. O., \& Oladele, J. O. (2016). Modulatory effects of Ricinus communis leaf extract on cadmium chloride-induced hyperlipidemia and pancytopenia in rats. Am. J. Biomed. Res., 4(2), 38-41.

Patil, A. J., Bhagwat, V. R., Patil, J. A., Dongre, N. N., Ambekar, J. G., \& Das, K. K. (2007). Occupational lead exposure in battery manufacturing workers, silver jewelry workers and spray painters in Western Maharashtra (India): Effects on liver and kidney function. J. Basic Clin. Physiol. Pharmacol., $18,87-100$

Patra, R. C., Rautray, A. K., \& Swarup, D. (2011). Oxidative stress in lead and cadmium toxicity and its amelioration. Vertirenary Medicine International, 47, 52-60.

Sinha, A. K. (1972). Colorimetric assay of catalase. Analytical Biochemistry, 47, 389-394.

Tabassum, B., \& Bajaj, P. (2013). Rejuvenation of cadmium induced electrolyte imbalance by Menthe piperita. Int. J. Sci. Res. Pub, 3(5), 1-4.

Tsao, R., \& Akhtar, M. H. (2005). Nutraceuticals and functional foods I: Current trend in phytochemical antioxidant research. Journal of Food Agriculture Environment. 3, 10-17.

Van Kerkhove, E., Pennemans, V., \& Swennen, Q. (2010). Cadmium and transport ions and substances across cell membranes and epithelia. Biometals. 23(5), 823-855.

Varshney, R., \& Kale, R. K. (1990). Effect of calmodulin antagonists on radiation induced lipid peroxidation in microsomes. Int. J.Radiat. Biol., 58:733-743.

Wang, B., Shao, C., Li, Y., Tan, Y., \& Cai, L. (2012). Cadmium and its epigenetic effects. Current Med. Chem. 19(16), 26112620. 